\title{
The Indigent's Right To Counsel In Civil Cases
}

A man whose life or liberty is jeopardized by a felony charge has a constitutional right to a lawyer. ${ }^{1}$ When his property ${ }^{2}$ is at stake, in a civil case, he may have a lawyer too-but only if he can afford to hire one. $^{3}$ This gap between the rights of poor criminal defendants and poor civil litigants was left undisturbed by the Supreme Court in October 1966, when it denied certiorari in the case of Sandoval v. Rattikin." Matias and Teresa Sandoval, an indigent and illiterate Texas couple, had sought to reverse a civil judgment on the ground that the state's failure to appoint counsel for them violated the Due Process and Equal Protection Clauses of the Fourteenth Amendment.

In a trespass-to-try-title action, the Sandovals had lost the two-room house in which they had-lived since 1945 with their nine children. Two weeks before their trial, their lawyer withdrew because they could not pay his fee, so they turned to the Nueces County legal aid attorney. He spoke only English and did not attempt to confer with his clients, who spoke only Spanish. His perfunctory preparation did not inform him that the "deed" on which plaintiff based his claim to the Sandovals" land was actually a mortgage, which under Texas homestead law could not confer title..$^{5}$

As the Sandovals' plight indicates, the actual concerns of the poor do not reflect the law's sharp distinction between civil and criminal litigants. Poverty only magnifies the importance of protecting one's property from seizure by legal process. The poor man may be evicted, his furniture may be repossessed, his welfare payments cut off, his children taken from him. Indeed, he may lose his liberty, through civil commitment to a mental institution. Conversely, he has vital interests which he

1. Gideon v. Wainwright, 372 U.S. 335 (1963). For the right to counsel in misdemeanor cases, see note 28 infra.

2. This Note does not deal with the area of the "quasi-criminal" action-cases civil in form but affecting the personal liberty of a party. Examples are habeas corpus, coram nobis, juvenile court, civil commitment, probation revocation, and deportation proceedings. In recent years many courts have taken the combination of Douglas v. Callifornis, 372 U.S. 353 (1963), and Smith v. Bennett, 365 U.S. 708 (1961), to compel appointment of counsel for indigents in such cases. See cases cited in Note, The Right lo Counsel in Civil Litigation, 66 Colum. L. REv. 1322 n.3 (1966); People v. Shipman, 62 Cal. 2d 226, 397 P.2d 993, 42 Cal. Rept. I (1965) (coram nobis hearing), noted in 13 U.C.L.A.L. REv. 446 (1966); but see Flowers v. Oklahoma, 356 F.2d 916 (10 Cir. 1960).

3. Powell v. Alabama, 287 U.S. 45, 69 (1932).

4. 395 S.W.2d 889 (Tex. Civ. App. 1965), cert. denied, 35 U.S.L. WeEr 3138 (U.S. Oct. 18, 1966).

5. The facts are most fully set out in the lower court dissenting opinion, 395 S.W.2d $889,894-901$. 
can only realize as a plaintiff in a civil action. He might be able to suspend rent payments for housing code violations, or get restitution for fraudulent or usurious credit transactions; he could protect his privacy and security against the arbitrary actions of welfare officials; get a divorce or a support, separation, or custody decree; or demand a hearing to challenge a civil commitment order. ${ }^{b}$

To meet such threats to their well-being poor people must turn to one of three sources of counsel: the private bar, organized private legal aid, and public legal assistance. None of these presently comes close to meeting the needs of the indigent for legal help. ${ }^{7}$

Most private attorneys work only for fees, which effectively bar the poor from access to their services. Private legal aid, long a major supplier of counsel to the poor, ${ }^{8}$ depends upon charitable contributions and volunteered services, and has never been able to supply more than a fraction of the needed services. ${ }^{9}$ Legal aid societies exist only in the larger cities, and not in all of them; ${ }^{10}$ where they do exist, they must set drastic standards of indigency for their clients, and still must turn away whole classes of civil cases for lack of the lawyers to handle them.11

Publicly supplied counsel may be provided as an adjunct of the right to proceed with a civil case in forma pauperis in the federal courts, and in the courts of a few states. ${ }^{12}$ However, appointment of counsel under such statutes is discretionary with the court, and in practice is grudgingly granted. ${ }^{13}$ In recent years, a different kind of public legal aid has

6. On the areas of civil litigation particularly affecting the poor, sce DEPARTMENT OF Heacth, Education, and Welfare, The Extension of Legat Serviges to thie Poor 17.69 (1964); National Conference on Law and Poverty, Proceedings 1.47 (1965); Wald, Law AND POVERTY 6-35, 40-42 (1965); Carlin \& Howard, Legal Representation and Class Justice, 12 U.C.L.A.L. REv. 381, 390-407 (1965).

7. On the inadequacy of the present effort, see Carlin \& Howard, supra note 6, at 407-21; Pye, The Role of Legal Services in the Antipoverty Program, 31 LnW \& ConTEMP. Proв. 211, 213-18 (1966). Cf. Clinton Bamberger, Jr., former Director of the Legal Services Program of the Office of Economic Opportunity: "The last estimate is that existing frec legal assistance for indigents reaches only $10 \%$ of the need." Address, Southwest Regional Conference on Legal Services to the Poor, Austin, Texas, March 25, 1966.

8. In 1964, 247 private legal aid offices handled 413,638 new civil cases at a cost of $\$ 4,357,453$. National Legal Ad and Defender Association, Summarx of Confereinge PROCEEDINGS (1965).

9. See sources cited supra note 7.

10. In April 1965, there were no legal aid facilities meeting the minimum requirements of the National Legal Aid and Defender Association in 130 American cities. Pye, supra note 7 , at 213 .

11. Legal Aid Societies often do not handle bankruptcy and divorce cases. Carlin \& Howard, supra note 6, at 413-16.

12. 27 Stat. 252 (1892), as amended, 28 U.S.C. \& 1915 (1964); ARK. STAT. ANN. § 27-401 (1962); Ill. Rev. Stat. ch. 33, \& 5 (1960); IND. StAT. ANN. \& 2-211 (1946); Kx. REv, STAT. \$ 453.190 (1960); Mo. ANN. Stat. \$ 514.040 (1952); NEw York Givil Practice Agr \& 196 (1955); Gen. Stat. No. CaR. \& I-1I0 (1953); TENN. Code ANN. § 29-201 (1955); TEX. STAT. ANN. art. 1917 (1964); VA. CoDe 14.1-183 (1964); W. VA. CoDE \& 5853 (1961).

13. On the federal courts' attitude, see Duniway, The Poor Man and the Federal 
emerged with the support of the Office of Economic Opportunity. ${ }^{14}$ Local programs supported by OEO grants are in some cases analogous to traditional legal aid societies. In other cases they represent a new and more aggressive approach to the legal problems of the poor. The OEO Legal Services Program has become the most important single source of legal assistance to the poor, but it has not yet nearly met the need. ${ }^{15}$

A constitutional mandate will spur philanthropic and legislative agencies to provide adequate counsel for those unable to hire their own. Such a mandate should not be long in coming. ${ }^{10}$ The doctrinal arguments for a right of civil counsel are simple. Indeed, the Supreme Court will have trouble resisting the logic of its own recent precedents. ${ }^{17}$ The Court's present caution must rest less on logic than on prudence-fear of burdening governments with an intolerable expense, and hence of causing itself unwanted political troubles. But the economic costs of providing full legal services to the poor cannot seriously strain the greatest industrial nation in the world. Political resistance can be softened by a graduated advance, resting temporarily with rules which draw the constitutional line short of an unqualified right to counsel.

\section{The Doctrinal Case for Appointed Civil Counsel}

\section{Due Process ${ }^{18}$}

The Supreme Court tied its 1963 grant of appointed counsel for indigent criminal defendants to the due process clause of the Four-

Courts, 18 STAN. L. REv, 1270, 1277-80; see also United States ex rel. Gardner v. Madden, 352 F.2d 792 (9th Cir. 1965); Weller v. Dickson, 314 F.2d 598 (9th Cir. 1963); Mfiller v. Pleasure, 296 F.2d 283 (2d Cir. 1961); Reid v. Charney, 235 F.2d 47 (6th Cir. 19j6); but sec Gift Stars, Inc. v. Alexander, 245 F. Supp. 697 (S.D.N.Y. 1965); Stiltncr v. Rhay, 322 F.2d 314 (9th Cir. 1963).

14. Under Title II-A of the Economic Opportunity Act of 1964, 78 Stat. 508, 516, 42 U.S.C. \$\$ 2781-91 (1964). The Legal Services Program of OEO is described in OFFICE OF ECONOMIC OPPORTUNITY, Justice (First Report to American Bar Association) (1960).

15. In the first eleven months of the program, between September 1965 and August 1966 , OEO made 160 grants totalling over $\$ 27,000,000$, and established over 500 new legal service offices. However, the program Ieft thirteen of the fifty largest American cities without OEO supported offices. OFFICE OE ECONOAIC OpPORTUNITr, op. cil. supra notc 14.

16. Mr. Justice Fortas, joined by Mr. Justice Douglas, apparently thinks the time is now. In dissenting from the denial of certiorari in Sandoval v. Rattikin, he said:

[T]his petition presents important issues as to the scope of the requirement, derived from the Due Process Clause of the Fourteenth Amendment, that state courts in civil actions must afford to each litigant a "proper opportunity to present his evidence". . The measure of constitutional protection afforded citizens who are recipients of free legal services, whether provided by the state or by primte charity is not less than that available to those who pay their own way. 35 U.S.L. WeEk 3138, 3139 (U.S. Oct. 17, 1966).

17. Miranda v. Arizona, 384 U.S, 436 (1966); Douglas v. Californin, 372 U.S. 353 (1963); Gideon v. Wainwright, 372 U.S. 335 (1963); Griffin v. Illinois, 351 U.S. 12 (1950).

18. This Note attempts no historical treatment of the rights of the poor in the civil 
teenth Amendment. But Gideon v. Wainwright ${ }^{10}$ leaves a gap between the right to counsel in criminal and civil cases which clashes with the very language of the due process clause. "[T] he Fourteenth Amendment extends the protection of due process to property as well as to life and liberty ..."-as Justice Roberts (laying the Constitution alongside the claim) had noted apprehensively in 1942, while restricting the right to free criminal counsel. ${ }^{20}$

It was sensible of the Justice to reason that a general right to counsel in criminal cases must also affect the civil process. The right to a lawyer derives from the due process right to a hearing. ${ }^{21}$ Its rationale was elaborated by Justice Sutherland in Powell v. Alabama:

The right to be heard would be, in many cases, of little avail if it did not comprehend the right to be heard by counsel. Even the intelligent and educated layman has small and sometimes no skill in the science of law. If charged with crime, he is incapable, generally, of determining for himself whether the indictment is good or bad. He is unfamiliar with the rules of evidence. . . . He lacks both the skill and knowledge adequately to prepare his defense, even though he [may] have a perfect one. . . . Without [counsel], though he be not guilty, he faces the danger of conviction because he does not know how to establish his innocence. ${ }^{22}$

Trying one's own civil case is just as difficult. A civil trial is conducted under technical rules of evidence and procedure; it demands skill in marshalling and presenting facts.

The Supreme Court has itself equated civil with criminal cases, en route to forbidding the states from barring any litigant's hired lawyer from the court room:

If in any case, civil or criminal, a ... court were arbitrarily to refuse to hear a party by counsel, employed by and appearing for him, it ... would be a denial of a hearing, and, therefore, of due process in the constitutional sense. ${ }^{23}$

In delimiting the right to representation by hired counsel, the Court has said that, inherently, any trial is so complex and involves such high

\footnotetext{
process. The historical evidence, which, if it is relevant at all, largely favors a due process right to appointed counsel in civil cases, is set out in a classic article, Maguire, Poverty
and Civil Litigation, $36 \mathrm{HARV}$. L. REv. 361 (1923).

19. 372 U.S. 385 (1963).

20. Betts v. Brady, 316 U.S. 455,473 (1942).

21. Powell v. Alabama, 287 U.S. 45, 68 (1982).

22. Id. at 68-69.

23. Id. at 69. Cf. Chandler v. Fretag, 348 U.S. 8,9 (1954).
} 
stakes that courts must not "indulge in nice calculations as to the amount of prejudice arising from its denial."

But the right of appointment of counsel has been sharply restricted.25 Before Gideon, judges in criminal cases with indigent defendants were asked to indulge in precisely the sort of "nice calculations" considered beyond their purview where a litigant had his own lawyer. To limit the right of appointment, the Court manipulated two factors: the complexity of the trial situation, and the defendant's stake in the proceedings. Against the complexity of each case it set off the defendant's abilities to master it - his intelligence, youth, experience, etc..$^{20}$ Further, the Court took into account what the defendant had to lose; it was quicker to require a lawyer in capital cases than in trials for lesser crimes. $^{2 \pi}$

The Court never explicitly justified its different treatment of the rights of appointment and representation, perhaps because the real ground of distinction-the fact that a right of appointment costs public money while a right of representation gives due process at bargain prices-was too embarrassing to state. With Gideon, the Court finally attacked the gap between representation and appointment-at least in serious criminal cases. ${ }^{28}$ It extended the Due Process Clause beyond the requirement that the client be allowed his money's worth of legal services.

The same extension should follow in the civil area. The Court's own decisions on the right of representation foreclose any claim that counsel is inessential in civil trials. It remains only to add that if an affuent litigant cannot get a fair trial without a lawyer, an indigent litigant cannot either.

24. Glasser v. United States, 315 U.S. 60, 76 (1942). Glasser was a Sixth Amendment case but the rationale of the right to counsel is the same under the Sixth Amendment and the Due Process Clause; see Johnson v. Zerbst, 304 U.S. 458, 463 (1938).

25. On a possible, though not persuasive, distinction between the right of appointment and the right of representation, see Israel, Gideon v. Thainwright: The "Art" of Overruling, in 1963 Sur. Cr. REv. 211, 243-45.

26. In right to counsel cases between Betts v. Brady, 316 U.S. 455 (1912), and Gideon v. Wainwright, 372 U.S. 335 (1963). For exhaustive review of these cases, see BEANEx, TrE Right to Counsed in AMERICAN Courts 160-91 (1955).

27. Hamilton v. Alabama, 368 U.S. 52, 55 (1961); Bute v. Mlinois, 333 U.S. 640, 674 (1948).

28. But the right to counsel in misdemeanor cases is still in doubt. For the Supreme Court's latest nonstatement on the issue, see Winters v. Beck (an apparenty unreported Arkansas decision), cert. denied, 35 U.S.L. WEEK 3139 (U.S. Oct 17, 1980) (Stewart, J., dissenting to denial of certiorari). Decisions favoring a right to counsel: ArcDonald v. Moore, 353 F.2d 106 (5th Cir. 1965); Harvey v. Mrississippi, 340 F.2d 263 (5th Cir. 1965); People v. Witenski, 15 N.Y.2d 392, 259 N.Y.S.2d 413, 207 N.E.2d 358 (1965); Tacoma v. Heater, 409 P.2d 867 (Wash. 1966). Contra, State v. Bennett, 266 N.C. 755, 147 S.E.2d 237 (1966). 


\section{Equal Protection}

Separate rights to counsel for rich and poor may deny equal protection as well as due process. In Griffin v. Illinois, the Supreme Court held that petitioner's inability to pay for a required trial transcript could not bar him from taking an appeal, on the principle that "there can be no equal justice where the kind of trial a man gets depends on the amount of money he has." 29 A successor case, Douglas v. California, required a state to appoint counsel for indigent defendants taking their first appeal, which was granted as a matter of right. ${ }^{30}$

Griffin and Douglas deal with the rights of indigents in the criminal process-to that extent they present circumstances more compelling than do civil cases, where litigants often have less at stake. On the other hand, Griffin and Douglas guarantee rights on appeal to the criminal accused-who has already had a trial at which to make his case-which are denied the civil litigant at trial, before he has had any hearing at all. The relative importance of criminal appeal and civil trial in our constitutional scheme is suggested by the reminder in Griffin that due process does not require the states to have any appellate system at all. ${ }^{31}$ It is difficult to imagine the Court holding that the entire system of civil trial courts is similarly dispensable.

The state cannot and need not equalize the impact on rich and poor of all its actions and institutions. ${ }^{32}$ But because the establishment of a forum for enforcing claims and vindicating legal rights is so fundamental, the state cannot close that system to any person because of his relative poverty.

Equal justice, unlike equal privileges on the municipal golf course, ${ }^{33}$ is a defining condition of citizenship. ${ }^{34}$ The Court has recently recognized that a $\$ 1.50$ poll tax treats those who cannot pay as second-class citizens. ${ }^{35}$ A $\$ 50$ or $\$ 100$ cover charge at the courthouse bears the same message. And when the state provides justice through an adversary system, which depends for its accuracy and fairness upon

29. 351 U.S. 12,19 (1956).

30. 372 U.S. 353 (1963).

31. 351 U.S. 12, at 18, 20-21, reaffirming McKane v. Durston, 153 U.S. 684 (1894). Commentators have questioned the contemporary vitality of McKane; see Willcox \& Bloustein, The Griffin Case-Poverty and the Fourteenth Amendment, 43 ConNELL L.Q. 1, 11 (1957); Note, The Supreme Court 1962 Term, 77 HAarv. L. REv. 62, 108 (1963).

32. Griffin v. Illinois, 351 U.S. 12, 23 (1956) (concurring opinion); Douglas v. California, 372 U.S. 353, 356-57 (1963).

33. Cf. Holmes v. City of Atlanta, 350 U.S. 879 (1955).

34. Willcox \& Bloustein, supra note 31 , at 16.

35. Harper v. Virginia Bd. of Elections, 383 U.S. 663 (1966). 
professional presentation of competing cases, the lawyer's fee is a cost imposed on the citizen by that system.

\section{The Costs of Counsel}

Before the Supreme Court declares a right to counsel in civil cases the law of the land, it will ask, quite simply: "Can the country afford it?" So far, at least, legal aid has not been straining our resources. In a recent year, about two billion dollars were spent in this country on private legal services, while all of four million were being spent on legal aid- 0.2 per cent. ${ }^{36}$

Even a full right of counsel should not be prohibitively expensive. Most of the industrial nations of the world, less wealthy than the United States, provide free legal services to the poor. Continental countries have long provided public legal assistance, in some cases since the First World War. ${ }^{37}$ Britain has had a statutory legal aid scheme since 1949.38 Many of these plans supply far more than trial counselaid on civil appeal, legal advice apart from litigation, and the services of investigators and expert witnesses. ${ }^{39}$

While the comparative and internal evidence strongly suggests that this country can afford a general right to counsel, it does not provide a reasonably accurate estimate of how much the right would cost. Such an estimate probably cannot be made at this time. Projection of foreign figures into the American legal system is not reliable.40 Nor is it possible to project current American figures into the new situation created by a constitutional right to counsel; ${ }^{41}$ we do not know how many long-submerged legal problems of the poor will emerge into litigation with the declaration of a right to counsel.

Public aid, in any of several alternative forms, will have to bear

36. Carlin \& Howard, supra note 6 , at 410 n.121.

37. Schweinburg, Legal Assistance Abroad, 17 U. CHr. L. REv. 270, $289-91$ (1950); C). United States v. Johnson, 238 F.2d 565, 573 (2d Cir. 195G) (Frank, J., dissenting opinion).

38. Legal Aid and Advice Act, 1949, 12 \& 13 Geo. 6, c. 51 . See generally, Utton, The British Legal Aid System, 76 YALE L.J. 371 (1967).

39. Schweinburg, supra note 37; Utton, supra note 38.

40. For what the figures are worth: Britain, with a Gross National Product about one-eighth that of the United States, spent about $\$ 24,000,000$ on its Iegal aid sjstem in 1964-65. Utton, supra note 38, at 377. Projected on the basis of G.N.P. alone, that gives a price tag of close to $\$ 200,000,000$ per year for the United States.

41. Total American expenditure on civil legal aid from private and public sources, supra notes 8 and 15 , is about $\$ 32,000,000$ per jear. How much this represents of the money needed to implement the rights argued for in this Note cannot be guessed. The estimate that ten per cent of the "need" is currently being met, sec Carilin \& Howard, supra note 6, at 409-10, is apparently based on pre-OEO figures, hence it probably is low. 
most of any new burden. ${ }^{42}$ The cost of this aid, while it will be small in relation to gross figures of public expenditure, is likely to look large indeed when compared with what Americans are used to spending on legal assistance.

The Supreme Court, in creating a constitutional right to counsel in civil cases, will be in effect issuing a mandamus to the legislatures to appropriate sufficient funds to pay for the right. The Court is likely to consider carefully the political acceptability of any decision which will place it in this position.

Because of the uncertainty of the cost, and the possible political difficulties involved in meeting it, the Supreme Court is unlikely to create a full-fledged right to counsel for all indigent parties in all civil cases at one time. Rather it is likely to develop the rights of indigents in the civil area cautiously, much as it has in the criminal area.

\section{The Path to an Unqualified Right to Appointed Givil Counsel}

In establishing expensive criminal procedural safeguards for the indigent, the Court has developed a warning technique. First there is a landmark case-a Powell or a Griffin-announcing the new right in broad terms, on their face applicable to a wide range of poor litigants. However, the actual holding is narrowed to apply only to a small number of cases. Subsequently, the effective scope of the right is gradually broadened, while the Court continues to reiterate the general principles which presage the still broader right which is to come.43

This technique requires resting points, at which the Court can halt expansion of the new right, while its implications are digested and institutions are developed to carry it into effect. A variety of rules can serve as intermediate stops on the way to a full right to civil counsel. But not all of these possibilities are equally serviceable.

42. The job is not likely to be done by uncompensated appointment of counsel. This system, unfair both to clients and lawyers, is under attack in the courts; Dillon v. United States, 230 F. Supp. 487 (D. Ore. 1964), reversed, 346 F.2d 638 (9th Cir. 1965); Lascher v. State, 64 Cal. 2d 746, 414 P.2d 398, cert. denied, 35 U.S.L. WEER 3162 (U.S. Nov. 7, 1966); State v. Rush, 46 N.J. 399, 412, 217 A.2d 441,448 (1966).

43. The process may be traced in cases running from Powell v. Alabama, 287 U.S. 45 (1932) to Gideon v. Wainwright, 372 U.S. 335 (1963), cited in note 27 stupra, note 46 infra, and in BEANEX, op. cit. supra note 26; also in cases following Griffin v. Illinois, 851 U.S.' 12 (1956): Burns v. Ohio, 360 U.S. 252 (1959); Smith v. Bennett, 365 U.S. 708 (I961); Lane v. Brown, 372 U.S. 477 (1963); and Draper v. Washington, 372 U.S. 487 (1963). See gencrally, Note, Equal Protection and the Indigent Defendant: Griffin and its Progeny, 16 STAN. L.
REv. 394 (1964). 
Betts Redivivus: Distinctions Based on Competence and Complexity Courts may try to limit the scope of a right of civil counsel by resurrecting the principles developed from Betts $v$. Brady. 4 Under Betts, two kinds of circumstances were relevant in deciding whether a criminal defendant had a right of appointment: the competence of the defendant, including his age, intelligence, education, and experience with the law; and the complexity of the factual and legal issues in the case. ${ }^{45}$

The Betts principles have two merits. First, they take into account the purposes of the right of counsel-protection of the litigant against being prejudiced by the weak presentation of a complicated case. Second, a body of case law interprets the principles. However, examination of the cases reveals the chief drawback of Betts. It was too vague a standard to guide reluctant state courts. When the state legislature lagged in the provision of counsel, the courts tended not to find "special circumstances." The Supreme Court's only recourse was to indicate that the circumstances of the case before them were indeed "special," and to reverse. ${ }^{46}$ When the Court tried to push the test in the direction of requiring counsel in more and more cases, as Justice Harlan remarked, "This evolution ... appears not to have been fully recognized by many state courts. . ..."4T

The "troubled journey" 48 of the special circumstances standard should discourage the Supreme Court from starting a second trip.

The Type of Civil Case: Rules Based on the Importance of the Interest at Stake

British legal aid excludes from its coverage actions involving injury to reputation: defamation, breach of promise to marry, and enticement of spouse.99 A widespread policy among Legal Aid Societies in this country is not to provide counsel for divorce actions."

Policies like this reflect the judgment that some civil actions are luxuries, less needful of subsidy than others. These judgments are no

44. 316 U.S. 455 (1942).

45. See BEANEY, op. cit. supra note 26 , at 160-91.

46. See, e.g., Chewning v. Cunningham, 368 U.S. 443 (1962); Ureges v. Pennsylvania, 335 U.S. 437 (1948); Wade v. Mayo, 334 U.S. 672 (1948); Rice v. Olson, 324 U.S. 786 (1945).

47. Gideon v. Wainwright, 372 U.S. 335, 351 (1963).

48. Id. at 350 .

49. Dworkin, The Progress and Future of Legal Aid in Civil Litigation, 28 Mod. I. REv. 432, 445 (1965).

50. Carlin \& Howard, supra note 6, at 413-15. 
doubt partly paternalistic or moralistic but insofar as they have a stronger basis, it is that less is at stake in the "luxury" actions. To this extent, these judgments parallel the distinction between capital and noncapital crimes, between felonies and misdemeanors, and between criminal and civil cases. They are subject to the same objections as those distinctions-that they make the poor man put a greater interest at stake, before he has counsel as of right, than a rich man must. This in itself is no conclusive objection; it applies to any distinction designed as an expedient limitation on the right of appointment of counsel.

Apart from this objection of principle, it is difficult to distinguish between kinds of civil actions on the basis of the "importance" of the interest at stake in them. In the largest class of civil cases, what is at stake on both sides is money, or property of definite economic value. Presumably the only line which could be drawn within this area would set a minimum on the financial stake which would compel appointment of counsel. Any such criterion ignores the crucial factor of relative poverty; to a very poor man, fifty dollars may make a great deal of difference. ${ }^{51}$

A constitutional argument might be mounted that only civil cases involving "property" give rise to the right of counsel, appealing to the language of the Due Process Clause..$^{52}$ It is hard to take such an argument seriously-would due process not be violated if one party were denied the right of representation by employed counsel in a divorce case?53

Other arguments excluding non-property interests as too "unimportant" rest on value judgments far more subjective than those underlying the rejected distinction between capital and noncapital crimes. ${ }^{54}$ Is the interest at stake in a divorce-freedom to remarrymore or less important than the interest in property? What shall the courts say of the interest protected by defamation suits-the interest in reputation? As the questions multiply, the distinctions fade.

51. In some jurisdictions this problem is dealt with, in theory, by the provision of small claims courts. On the practical weaknesses of small claims courts as forums for the poor, see Carlin \& Howard, supra note 6, at 421-23; WALD, op. cit. supra note 6, at 62-64.

52. See Betts v. Brady, 316 U.S. 455, 473 (1942).

53. For the argument that the term "property" in the Due Process Clause should be construed to mean "all legal interests," see Newman, The Process of Prescribing "Due Process," 49 CALIF. L. Rev. 215, 218 (1961).

54. See Mr. Justice Clark concurring in Gideon: "[The] distinction between capital and noncapital cases ... [is] a value judgment not universally accepted." 372 U.S. 335,849 (1963). 


\section{Plaintiff-Defendant: Distinctions Based on Volunlariness}

A major talking point of those who oppose expansion of the legal rights of the poor is the spectre of a flood of frivolous and harassing lawsuits by the poor. ${ }^{55} \mathrm{~A}$ simple way to appease this fear would be to grant the right only to civil defendants, letting indigent would-be plaintiffs get along on private legal aid and contingent fee arrangements.

The rhetorical key to the plaintiff-defendant distinction is the phrase "haled into court," as used, for instance, by the Supreme Court in Gideon v. Wainwright: "[A]ny person haled into court, who is too poor to hire a lawyer, cannot be assured a fair trial unless counsel is provided for him." 56 Behind this rhetoric is no doubt some sense that one who finds himself brought into court, against his will, to have some civil interest threatened, is more deserving of sympathy (and a lawyer), than one who chooses to come to court with a claim.

But the plaintiff-defendant distinction is, in essence, arbitrary. Suppose Burt pays money to Harry, and a dispute arises over whether the payment is a loan to Harry or the discharge of a previous obligation of Burt's. Under the plaintiff-defendant distinction, impecunious Burt cannot get a lawyer to sue Harry for the money, thus Harry wins the dispute by default. If Burt had not made the payment, it would have been Harry who was financially barred from having a fair hearing on his claim. The outcome of legal disputes should not have to depend on such fortuities.

Or consider Mr. and Mrs. Kramden, indigents, who do not get along. It will be in the interest of each to try and goad the other into first filing divorce papers; the winner in this war of nerves will emerge with a lawyer, while the loser gets none, under the plaintiff-defendant distinction.

The procedural alignment of a dispute into "plaintiff" and "defendant" has little to do with the voluntariness or deserts of the parties. A better way should be found of discouraging frivolous or harassing litigation.

55. See Moore v. Cooley, 2 Hill 412, 413 (N.Y. Sup. Ct. 1842): "[T] he pauper comes to litigate entirely at the expense of others. .. He thus enjoys a great privilege and exemption from the common lot of men, whereby ... he becomes, as Lord Bacon says rather able to vex than unable to sue." For more contemporary expression of the same concern, see Hamley, The Impact of Griffin $v$. Illinois on State Court-Federal Court Relationships, 24 F.R.D. 75, 80-81 (1958); Qua, Griffin v. Illinois, 25 U. Cu. L. REv. 143, 149 (1957).

56. 372 U.S. $335,344$. 
The Public Plaintiff: Distinctions Based on the Role of the State in the Case

Among the clearest cases of injustice in the civil process are those in which the state brings suit against an indigent and unrepresented defendant-whether in its role as tax-collector, condemnor of property, landlord, or parens patriae. The defendant, unable because of his poverty to present his case properly, is overborne by lawyers and other litigative resources paid for out of the public treasury.

The striking unfairness of such proceedings might tempt a court to hold, as an initial step toward a general right of appointed civil counsel, that a lawyer must be appointed for an indigent defendant only against a public plaintiff.

Such a limitation on the right of civil counsel would have practical advantages. It would give the state the power, which it now has in the criminal field, to limit the pressure upon local legal aid resources by reducing the number of suits it brings against poor defendants. No such power exists when counsel must be appointed in civil suits between private parties.

But there are both common sense and doctrinal objections to the "public plaintiff" rule. First, in considering the case from the point of view of the poor defendant, a judge will be hard put to find him more unfairly treated when his opponent is the state than when it is a private party, equally well supplied with counsel and other litigative services. Second, the rule would presumably be based on the state action doctrine-and it would be bad constitutional law to hold that no state action is present unless the state is a party to the suit. ${ }^{57}$ The "public plaintiff" rule, if framed as a constitutional doctrine, would implicitly deny that the state "acts" in the Fourteenth Amendment sense when it establishes its system for settling private disputes.

Statutory Manipulation: Distinctions Between State and Federal Courts

A familiar device for warning the states of the onset of a costly constitutional obligation is the initial imposition of that obligation on the federal government alone. An example of such a warning is the Supreme Court's development of the right of appointment of counsel for criminal defendants. The right was declared, though applied under

57. See, for contemporary interpretation of "state action," Burton v. Wilmington Parking Authority, 365 U.S. 715 (1961); Evans v. Newton, 382 U.S. 296 (1966); Henkin, Shelley $v$. Kraemer: Notes for a Revised Opinion, 110 PA. L. REv. 473 (1962); Silard, $A$ Constitutional Forecast: Demise of the 'State Action' Limit on the Equal Protection Guarantee, 66 CoLUM. L. REV. 855 (1966). 
the Sixth Amendment only in the federal courts, in the case of Johnson v. Zerbst. ${ }^{58}$ Not until twenty-five years later did the Court extend the full right to the states by incorporating it in the Fourteenth Amendment. ${ }^{59}$

No such two-step is possible with the right to civil counsel, for the constitutional provisions which support the right apply equally to the states and the federal government. However, there remains the technique of creating a right to appointed civil counsel in the federal courts by means of a constitutionally "influenced" reinterpretation of a federal statute.

An appropriate statute is available: 28 U.S.C. $\S 1915,{ }^{10}$ which authorizes federal courts to allow civil litigants, as well as criminal appellants, to proceed in forma pauperis if they are "... unable to pay ... costs or give security therefor," and which further provides that " $t]$ he court may request an attorney to represent any such person unable to employ counsel...."

The provisions that a court "may" waive payment of costs and "may" supply a litigant with counsel appear to grant the trial judge broad discretion; the statute itself provides no standards for the exercise of that discretion. However, the Supreme Court, interpreting these phrases as they apply to criminal appeals, has shown how apparently permissive and discretionary statutory language can, under the influence of constitutional doctrine, be stretched to require a right to appeal in forma pauperis and a right of appointed counsel.

The constitutional influence was Griffin $v$. Illinois ${ }^{\circ 1}$ in 1956, which required the states to provide in forma pauperis appeals to all indigents convicted of crime. A year after Griffin, the Court decided that when a trial court certified that an appeal was not taken in good faith (and thus could not be pursued in forma pauperis), such certification could be appealed, and counsel must be appointed by the appellate court to argue the issue of good faith.02 Second, the Court held that all appeals were, as a matter of law, taken "in good faith" unless they were so frivolous as to be subject to dismissal by a judge sua sponte under Federal Criminal Rule 39(a). ${ }^{63}$ Finally, the Court held that where an

\footnotetext{
58. 304 U.S. 458 (1938).

59. Gideon v. Wainwright, 372 U.S. 335 (1963).

60. 27 Stat. 252 (1892), 28 U.S.C. $\$ 1915$ (1964).

61. 351 U.S. 12 (1956).

62. Johnson v. United States, 352 U.S. 565, 566 (1957).

63. Ellis v. United States, 356 U.S. 674 (1958).
} 
in forma pauperis appeal was allowed, counsel should be appointed to argue the appeal on the merits. ${ }^{64}$

The Court explained, quite unnecessarily, that this tour de force of statutory interpretation had been

. . impelled by considerations beyond the corners of 28 U.S.C. $\S 1915$, considerations that it is our duty to assure to the greatest degree possible, within the statutory framework for appeals created by Congress, equal treatment for every litigant before the bar. ${ }^{05}$

Similar interpretive work could be done with the provisions that courts "may" permit civil cases to proceed in forma pauperis, and "may" appoint lawyers for litigants who cannot afford to pay for them. The Court clearly has the power to set standards for the exercise of discretion by trial courts in making the judgments called for. It could hold that federal courts must grant counsel and waiver of costs, except when certain specified circumstances are present, and it could accompany this holding by a version of its statement that it was "impelled" by considerations of "equal treatment for every litigant before the bar."B6

Costs and Counsel: Distinctions Between Access to the Courts and Effective Use of Them

A final signalling device could be the declaration of a constitutional right of free access to the courts. All civil courts require plaintiffs, and usually defendants as well, to pay certain court fees, and to post bond which will cover costs in the event that they lose the case. ${ }^{07}$ These fees and costs often prevent the poor from having any hearing at all on the merits of their case.

This barrier is arguably a worse discrimination against the poor than the failure to provide counsel. If the indigent litigant can get into court, he has at least some chance of convincing a judge or jury of the merit of his case or defense, even if he has no lawyer to put his case for him. Where he cannot even gain access to the court, he has no chance at all.

64. Coppedge v. United States, 369 U.S. 438, 446 (1962).

65. Id. at 446-47.

66. In doing so, the Court would not have to depart from its own precedents; it has ruled on appointment of civil counsel under $\S 1915$ only once, and there to relax the standard of indigency applied. Adkins v. E. I. DuPont de Nemours \& Co., 335 U.S. 391 (1948).

67. Amierican Bar Foundation, Public Provision for Costs and Expenses of Civil Limigation 1-7, 91-100 (tentative draft, 1966). 
The distinction has the practical merit that the states are institutionally better prepared to waive fees and costs for the poor than they are to provide free counsel. Most states now have civil in forma pauperis laws; 68 those which do not could easily enact them without the strain that might be caused by trying to find enough lawyers to represent all indigent civil litigants.

This no-fees approach was adopted by the Supreme Court in developing the rights of the poor in criminal appeals. The Griffin case and its immediate successors guaranteed a right of access; only seven years later with Douglas v. Califormia ${ }^{63}$ did the Court reach out to require appointment of counsel. The distinction may serve a useful warning function, but ultimately it is a fragile one. The right to bring or defend a lawsuit without an accompanying right of counsel is, in most cases, hollow. A realistic court could not long reconcile granting a right of access to the courts with denial of the rights which make access effective. ${ }^{\text {T0 }}$

\section{Administration of Appointment of Civil Counsel ${ }^{71}$}

If the Supreme Court declares a right to civil counsel, the states will take care to prevent assignment of counsel in frivolous cases. The courts will have to review these screening systems for violations of the due process and equal protection rights of the applicants. Both substantive conditions and procedural arrangements will pose constitutional problems.

\section{Substantive Standard}

Why should any screening for legal merit be allowed at all? The rich man does not have to make any showing of a good case to get an appointment with a lawyer. And in Douglas, the Supreme Court held

68. Id. at 3 .

69. 372 U.S. 353 (1963). The access-counsel distinction is discussed in Comment, 55 MrCF. L. REv. 413, 420 (1957).

70. Justice Jackson: "[R]ights' are worth, when they are threatened, just what some lawyer makes them worth." The County Seat Lawyer, 36 A.B.A.J. 497 (1950).

71. To administer a right to appointed civil counsel, courts must establish a standard for determining to whom the right applies. The problem exists as vicll in the field of criminal right to counsel, and this Note does not deal with it. One possible standard has been suggested by the Allen Committee:

[P]overty must be viewed as a relative concept. ... A problem of poverty arices for the system of criminal justice when at any stage of the proceedings lack of means in the accused substantially inhibits or prevents the proper assertion of a right or a claim of right.

Attorney General's Comamtiee, Poverty and the Adamistration of Federat Couminal JUSTICE 7-8 (1963). 
that an indigent defendant could not be required to "run this gauntlet of a preliminary showing of merit."'72

Here a distinction can be made between the civil and criminal spheres. A man who visits a lawyer on a civil matter may have a view to possible litigation; on the other hand, he may desire some other service -the drafting of a will, or merely some advice. It is certainly arguable that there is a general right of the poor to have legal advice for free, but such an argument goes beyond the narrower one made here: that the right to use the courts, to litigate, is so fundamental that a state must make it equally available to all.

One possible threshold might be called a "cause of action" standard: if the applicant can state facts which constitute a cause of action or a defense legally sufficient for him to proceed to litigation, he should have counsel appointed to represent him.

Such a standard finds a precedent in the Supreme Court's test for in forma pauperis appeals of criminal convictions under 28 U.S.C. $\S 1915$. The Court has required that such appeals be allowed (and thus that counsel be appointed) if the defendant can state a ground of appeal which would prevent sua sponte dismissal by an appellate court if the appeal had been brought by a non-indigent party. ${ }^{73}$

Given a goal of rough equality of litigative services between rich and poor, the "cause of action" standard is appropriate to the criminal appellate process. A convicted defendant who is told by his lawyer that he has a ground for appeal is likely to spend his last cent pressing the case. ${ }^{74}$ But a stronger test than "cause of action" may be permissible in the civil area, where financial factors do play a large part in the decisions of non-indigent persons to drop or to press a case. Almost no one is so extravagantly litigious that he will enter a lawsuit on the bare advice of counsel that he can state a legally sufficient cause of action or defense. The application of the "cause of action" standard to the right of civil counsel might place the poor in a better position than those who must

72. 372 U.S. 353,357 (1963). The problem need not arise if the right to civil counsel is based on the Due Process Clause, which traditionally guarantees only a minimum standard of fairness. The guarantee of substantially equal services to rich and poor is an equal protection requirement, stemming from Grifin, and particularly from Douglas.

73. See note 63 supra.

74. Cf. Draper v. Washington, 372 U.S. 487,495 n.4 (1963):

The state also argues that in practical effect there is no difference at all between the rights it affords indigents and nonindigents, because a moneyed defendant, motivated by a "sense of thrift," will choose not to appeal in exactly the same circumstances that an indigent will be denied a transcript. We reject this contention as untenable. It defies common sense to think that a moneyed defendant faced with long term imprisonment and advised by Counsel that he has substantial grounds for appeal ... Will choose not to appeal merely to save the cost of a transcript. 
hire their lawyer; that far the states may not have to go. The standard applied by the British Legal Aid and Advice Act of 1949 may be the best one available. In Britain, a committee of attorneys judges whether:

... a man of moderate means (sufficient to afford the costs of litigation but not in a position to waste money) would embark on litigation relying on his own means; whether, in effect, it would be "reasonable business" to take action. ${ }^{75}$

The standard has the drawback of vagueness, which may encourage lax administration by state courts. Unfortunately it is difficult to formuIate any standard less stringent than the "cause of action" test which does not raise the same problem. Some of the difficulties of enforcement can be met by requiring that fair procedures be followed in the decision to grant or deny counsel; others must be overcome by the Court's embellishing the "private client" test with a body of case law.

\section{Procedure}

The procedure for administering the standard of merit imposed on applications for counsel must avoid two unconstitutional extremes. It must not be so informal as to afford no opportunity for review-important constitutional rights cannot be granted or withheld by officials exercising unfettered discretion. ${ }^{70}$ On the other hand it must not be so formal and complex as to replace, in effect, the trial which the applicant for counsel is seeking. ${ }^{77}$

These two extremes suggest the ground rules for an acceptable procedure. It might make use of a frontline screening agency, whether a judge, a private lawyer operating under a scheme of state reimbursements, an official or private legal aid agency, or a public or private referral service. If the agency should decide that the applicant's case did not merit the appointment of counsel, it would inform him of that decision, and that he had a right to a hearing if he wished to challenge it.

The hearing itself should be an informal ex parte proceeding, either before a judge or a quasi-judicial administrative board. The applicant should be allowed and encouraged to tell his story in his own way, without any strict standards of relevancy or other rules of evidence being applied. Presumably he could be placed under oath, and the

75. SACES, Legal Aid 82 (1951).

76. Lane v. Brown, 372 U.S. 477, 485 (concurring opinion) (1963).

77. Cf. McKenna, Judicial Safeguards of the Rights of Indigent Defendants, 11 NoTse DAsre LAw. 982, 993 (1966). 
hearing officers could be allowed to question him. A record should be kept of the hearing, and a finding of fact and a reasoned decision should be written by the judge or the board. If the hearing is administrative, it should be subject to judicial review. 